that this body of scholarship tends to improperly identify the Civil Rights Movement as the "parent" movement; he questions the usefulness of the wave metaphor in order to understand and deconstruct US feminist struggles. Though it might be useful to construct an alternative genealogy, to conceive of black radical feminism in this "parent" metaphor might inadequately conceal its multiple influences over time and space in favour of privileging a single point of origin.

Nonetheless, McDuffie's work is a thorough and focussed study that will no doubt help shift the conversation and offer a wide analysis of black leftist women's collective engagement with black radicalism during, and beyond, the Old Left period. McDuffie's study usefully demonstrates that black women not only collectively forged their own coherent, separate, radical praxis, but his also analysis historicizes postwar radical black feminism, demonstrates how black left feminism evolved over time and space, and contextualizes black radicalism's long history as invariably informed by a complex interplay of gender, race, sexuality, class and politics.

Francesca D’Amico

York University

\title{
Marcus Rediker, The Amistad Rebellion: An Atlantic Odyssey of Slavery and Freedom (New York: Viking Penguin, 2012).
}

Marcus Rediker's The Amistad Rebellion: An Atlantic Odyssey of Slavery and Freedom (2012) makes a major contribution to our understanding of "one of the most important events of its time" (3). According to Rediker, "the history and movie have told only part of the story" (5). Indeed, although the Amistad story is well known, the role-played by the multi-ethnic group of West African rebels from Southern and Eastern Sierra Leone has not been given enough attention. For too long, "the drama of the courtroom has eclipsed the original drama that transpired on the deck of the slave schooner. The American actors ... have elbowed aside the African ones whose daring actions set the train of events in motion" (5).

Challenging American triumphalism and the predominant focus on American abolitionists, politicians, judges and law makers that has characterized other scholarly work, Rediker takes the Amistad Africans previously placed in the background and at the margins of other Amistad studies, and places them in the foreground, at centre stage. His "history from below" makes known the fortynine men and four children who journeyed together, first as slaves on the Gallinas Coast, then as shipmates who survived the brutal Middle Passage, only to be reshipped from Havana and loaded on the Spanish-led Amistad schooner destined for sugar plantations in Puerto Príncipe. Situating their rebellion and legal triumph from 1839 to 1841 within an "Atlantic geography of resistance," 
Rediker provides a wonderfully detailed account of how and why they succeeded. As he notes, the members of this diverse group carried anti-slavery knowledge with them across the Atlantic, and some had valuable training and experience in guerrilla warfare.

Based on research he completed for The Slave Ship: A Human History (2007), winner of the George Washington Book Prize, this more hopeful book begins where most studies of the Amistad have not -- with the West African origins of the rebels. As Rediker argues, "Everything the rebels did, from the moment of enslavement to the moment of repatriation and afterward, was based to a large extent on their experiences in Africa before capture" (21). Understanding where the Amistad Africans came from is important. Rediker is at his best as he skillfully nuances the particular socio-cultural context in which these individuals from nine different groups formed bonds premised on their multiple, overlapping identities and shared trauma. As he explains, based on common experiences of culture, work and self-organization in West Africa and their collective struggles between 1839 and 1841, they formed a "fictive kinship". Indeed, during their court case, the Amistad rebels self-identified as one group with a new collective name: "The Mendi People" (179). This example of bonding and shared identity in order to further collective goals challenges Orlando Patterson's thesis that all slaves went through a social death.

Rediker's study also reveals the direct contact the Amistad Africans had with translators and thousands of people who traveled to visit and interview them while they were in jail in New Haven after being captured by the United States Navy on the north coast of Cuba. The explosion of newspaper stories, plays, research studies, publications, abolitionist materials, drawings, engravings, wax figures and images of "The Mendi People" inspired by their successful revolt galvanized people, both near and far, to demand they be freed and treated with basic human dignity. This bolstered the campaign against the American legal system that held approximately two and half million Africans in bondage in 1839 and efforts to help fugitive slaves escape to Canada through the Underground Railroad that emerged in the same period.

If this book has a weakness, it is perhaps its lack of gender analysis and content on women and girls. We learn that the three female rebels - young girls named Margru, Kagne, and Teme - found the machetes used by Cinqué and the other men during the Amistad uprising, and were held against the group's wishes by William Pendleton, the brother of their jailer in New Haven. Unfortunately, Rediker does not expand on the role these girls played in the rebellion, nor does he address the differences they experienced by virtue of their gender. Similarly, Rediker notes that women abolitionists visited the rebels, but he provides little analysis on the roles they played in "abolitionism from below." As Clare Midgley and others have noted, the contributions of women to anti-slavery, like the fundamental oppositions between free and forced labour on which arguments 